Reprinted from the "Proceedings of the Indian Academy of Sciences," Vol. LII, 1960

\title{
ON THE EARLY DEVELOPMENT OF AN OPHICHTHYID EGG FROM THE LAWSON'S BAY, WALTAIR
}

BY

R. Velappan NaIR and (Miss) M. Dharmamba 
Reprinted from "The Proceedings of the Indian Academy of Sciences",

Vol. LII, No. 5, Sec. B, 1960

\section{ON THE EARLY DEVELOPMENT OF AN OPHICHTHYID EGG FROM THE LAWSON'S BAY, WALTAIR*}

By R. Velappan Nair and (Miss) M. Dharmamba

(Central Marine Fisheries Research Station, Mandapam Camp)

Roceived September 1, 1960

(Communicated by Dr. N. K. Panikkar, F.A.sc.)

\section{INTRODUCTION}

THE eel eggs are relatively rare in the Indian coastal waters and consequently their occurrence has been recorded only on a few occasions. Aiyar, Unny and Varkey (1944) were the first to observe the presence of eel eggs in the plankton of the Madras coast, but since the full paper has not so far been published details regarding the eggs are not available. Nair and Bhimachar (1950) recorded the occurrence of a few eggs and early larvæ of the eels in the plankton off Tuticorin Bay, Gulf of Mannar. Their account deals with three varieties of eel eggs of which one was with an oil globule while the other two were without it. They also described two types of preleptocephaline larvæ which showed differences in the myotome number and pigmentation. Jones and Pantulu (1955) described three preleptocephaline larval stages obtained by rearing the eggs collected from the Madras plankton and as pointed out by them there is no evidence to show that the larva belong to the same type of egg. . Bapat (1955) noted the presence of an eel egg without oil globule and which resembles Egg II, described by Nair and Bhimachar, in the plankton of Palk Bay and Gulf of Mannar and gave brief notes on the newly hatched larva obtained by rearing the eggs in the Laboratory.

The material for this study was obtained in the living condition from the regular plankton collections made from the Lawson's Bay, Waltair. The collections were made in the early morning hours with a bolting silk (No. 2) $\frac{3}{4}$ metre townet at a distance of about 3 miles from the shore where the depth is about 10 fathoms. This type of egg occurred in very small numbers in the townet collections made during the month of February, 1959, and they were reared in the Laboratory for obtaining the different stages described

- Published with the permission of the Chief Research Officer, Central Marine Fisheries Research Station, Mandapam Camp.

220 
here: It was not possible to trace the larval development further owing to the paucity of the eggs in the collections.

\section{EGG}

The egg is transparent; large and perfectly spherical measuring $2.95 \mathrm{~mm}$. in average diameter with a very wide perivitelline space. In the earliest
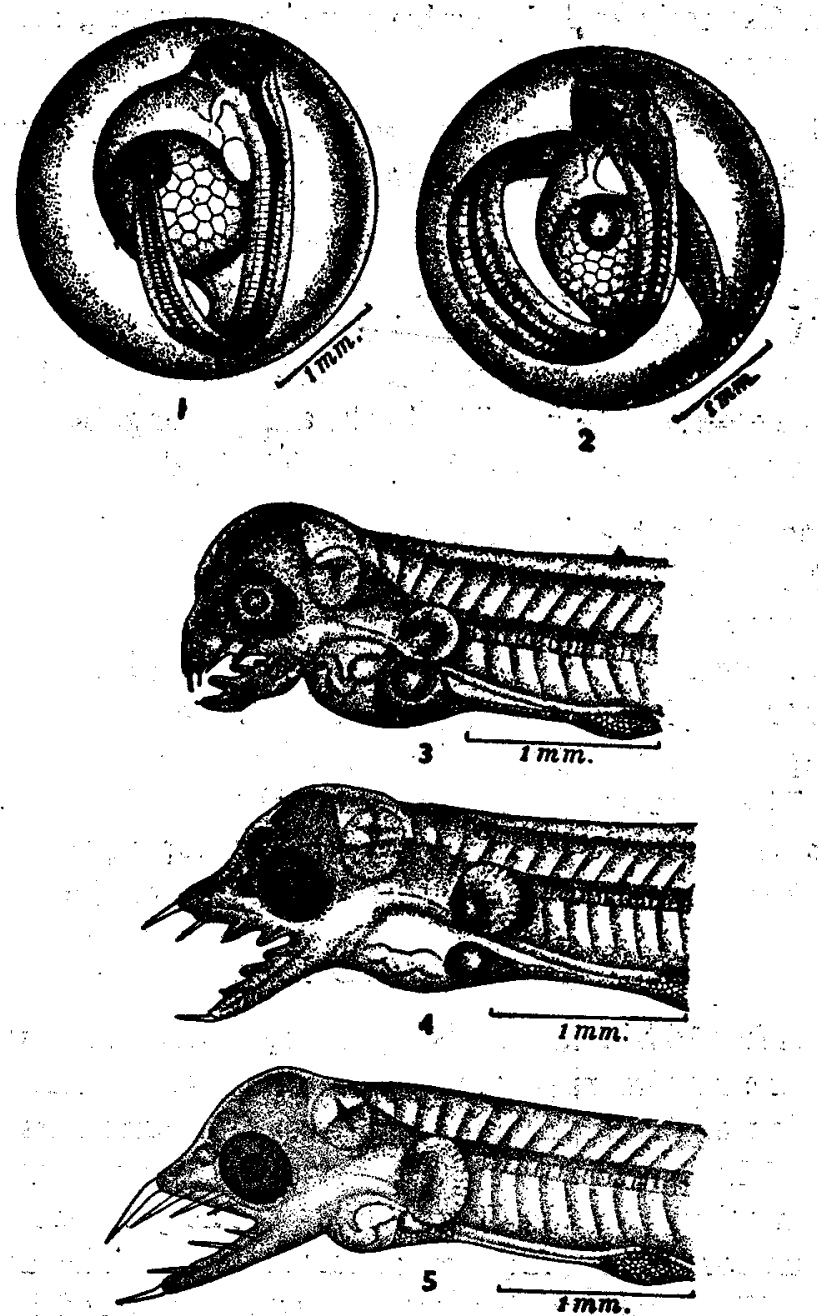

Tbxt-Fras. 1-5. Fig. 1. Egg showing the earliest embryonic stage in the collection. Fig. 2. Egg showing the final embryonic stage just before hatching. Fig. 3. Head region on the one-day old larva. Fig. 4. Head region of the two-day old larva, Fig. 5. Head region of the three-day old larva. 
developmental stage in the collection, the embryo is well formed with its posterior half free from the yolk mass (Text-Fig. 1). The yolk mass is clear, segmented and oval in shape. It is provided with a single yellow oil globule which is $0.4 \mathrm{~mm}$. in diameter. A narrow posterior prolongation of the yolk mass extends on the ventral side up to the middle of the free portion of the embryo. The eyes, auditory vesicles and cesophageal pouch are well developed and the heart is functional in this stage. The myotomes have differentiated and several myotomes are present in the embryo. The larval finfold is seen distinctly and the embryo makes wriggling movements inside the egg membrane.

Minute brow chromatophores are present on the ventral side of the embryo behind the yolk mass and in its caudal region.

The final stage in the embryonic development just before hatching is shown in Text-Fig. 2. The cmbryo has grown considerably longer and lies curled up inside the egg membrane making frequent vigorous wriggling movements inside it.\%. The yolk mass has become smeller with the oil globule situated in its antetior region. The backward prolongation of the yolk mass now extends more or less up to the posterior third of the embryo.

The pigmentation has become more defined and the pattern conforms to the ophichthyid pigmentation observed by Schmidt (1913) and Delsman (1933). Five groups of black ramifying chromatophores are present on the ventral preanal portion of the embryo behind the yolk mass and a network of similar chromatophores is also present on the caudal tip. The first two pigment groups are small while the others become larger and prominent posteriorly. The third group is situated at the tip of the prolongation of the yolk mass while the fifth group is near the developing vent. Minute black pigment cells have appeared in the posterior region of the eye.

\section{ONE-DAY OED LARVA}

The larva after 24 hours, is perfectly transparent and measures $10.93 \mathrm{~mm}$. in length with the maximum height in its middle region (Photograph 1). The posterior portion of the larva tapers gradually and terminates in the narrow. rounded tail. The head is somewhat round in shape with the developing mouth subterminal in position (Text-Fig. 3). The jaws are very short and show the formation of the first set of larval teeth. The dental formula is $1+3 / 1+3$. The teeth are slender, pointed and covered by tissues and in both the jaws the grasping teeth are the longest while the others decrease in size backwards. The gape of the mouth extends to about the posterior third of the eye. The snout is very short and the nasal pit is situated in frong 
An Ophichthyid Egg from the Lawson's Bay, Waltair

TABLE I

Measurements of the preleptocephaline larval stages

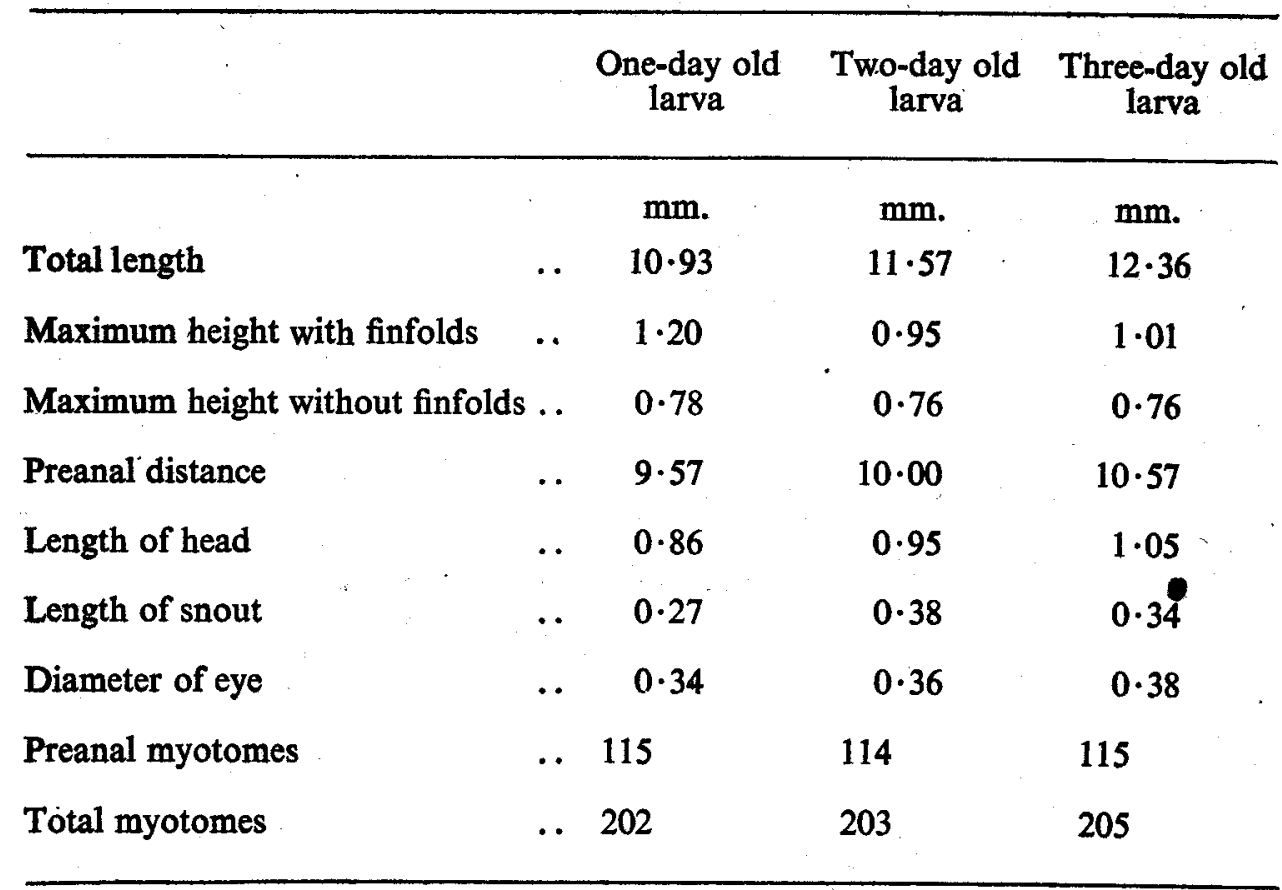

of the eye and the latter is slightly oval in shape. The auditory vesicles have grown larger in size and are seen clearly. The yolk mass has become considerably smaller and its backward extension has broken up into four oval yolk pockets situated below the alimentary canal and also the first four groups of pigment cells. The myotomes are clearly seen especially in the preanal region and they become narrow and compactly arranged in the caudal region. The larva possesses about 202 myotomes of which 115 are preanal in position. The alimentary canal is very long, straight and the vent does not open to the outside. The pectoral fin has begun to develop and is seen as a flap-like structure. The finfold is continuous and begins from the nape and terminates on the ventral side at about the anterior third of the larva. The dorsal finfold is wide in the middle region of the larva.

There is no change in the pattern of pigmentation from that of the final embryonic stage. The head is unpigmented except the eye which is brown in colour due to the accumulation of brown chromatophores. One more ventral pigment group has formed in this stage and altogether 7 groups of branching brown chromatophores are present of which six are preanal in 
position while the last one is at the tip of the tail. Each group is composed of several pigment cells. These groups are located above the alimentary canal and at the bases of myotomes 13-14, 23-24, 37-38, 53-56, 73-76 and 102-108. The post-anal ${ }_{i}$ group surrounds the caudal tip and almost covers it. In addition to these large groups three very small groups, each composed of 2-3 pigment cells, are also present in between the last four large groups of chromatophores. Of these small groups, two are preanal in position and are found on myotomes 64 and 88 while the third is post-anal and is on myotomes $123-124$.

\section{Two-Day Old LaRva}

The two-day old larva has increased slightly in length and measures $11.57 \mathrm{~mm}$. A slight reduction in the height is seen and this is caused by the elongation of the larva and also by the slight decrease in the width of the finfold. However, the maximum height continues to be in the middle region of the lafva. The head has grown longer than in the previous stage with welldeveloped mouth and jaws (Text-Fig. 4). The lower jaw is slightly longer than the upper. The dental formula continues to be the same and the teeth have become longer and are directed forwards. All the grasping teeth and the second pair of teeth of the upper jaw are exposed while the others are still covered by tissues. The snout has become pointed and the nasal pit is seen distinctly. The yolk mass has almost disappeared in this stage. The four yolk pockets are still seen distinctly though they are somewhat smaller in size. The oil globule has become smaller and it is covered by the remnants of the yolk mass. There is no change in the alimentary canal and the type specimen shows 114 preanal and 89 post-anal myotomes. The pectoral fin has grown larger in size. The anterior portion of the finfold has become very narrow and almost indistinguishable from the body.

The eye is black and partly silvery in colour. The pigment patches along the ventral side are more prominent and brownish-black in colour. These are situated on myotomes 13-14, 23-25, 35-36, 51-53, 71-75 and 101-104. The three small groups are on myotomes 62, 87 and 121-122. A few brown pigment cells have appeared at the base of the pectoral fin.

\section{Three-Day Old Larva}

The three-day old larva shows further increase in length and it mcasures $12.36 \mathrm{~mm}$. The head has also grown longer with a pointed snout (Photograph 2 and Text-Fig. 5). The teeth in both the jaws have become longer and stronger than in the previous stage. The grasping tooth of the upper 
jaw is very large and finely pointed while the others become smaller in size with the last one about one-fourth that of the grasping tooth. The teeth of the lower jaw are also long and pointed, but they are of about the same size. The yolk mass has completely disappeared while the oil globule is still seen even though it has lost its globular shape and is much smaller in size. The yolk pockets have also become smaller.in size. The myotomes are distinct and about 205 myotomes are present in the type specimen with the vent situated below the 115 th myotome.

The silvery eye and the ventral black pigment patches are very conspicuous in this stage. The ventral groups have assumed a linear shape and the preanal ones are situated on myotomes $13-14,23-25,36-38,51-54,76-80$, and 102-106. 'The three small groups have also become prominent and are on myotomes $63-64,88-90$ and $123-25$. In addition to these, one more small group has appeared in between the third and the fourth large group and it is on the 44th myotome. The chromatophores at the base of the pectoral fin have also become conspicuous by the formation of more pigment cells and these pigment patches on the ventral side give a characteristic dotted appearance to the larva.

\section{Genteral Remarks.}

The identification of the eggs and preleptocephaline larval stages of eels is extremely difficult owing to the presence-of the leptocephaline stage in the life-history of these fishes. The first successful attempt at identification by Schmidt (1913) was made possible only after getting the large 'Thor' collection of the transitional stages ranging from the tiny larvæ to the full grown leptocephalus. He found that the pigmentation and to some extent the number of myotomes are of great diagnostic value in identifying the youngest stages including the embryos. Based on the study of the 'Thor' collection made in the Mediterranean, Schmidt was able to identify the eggs and preleptocephaline larval stages of Murana helena, Nettastoma melanurum, Ophichthys serpens, Ophichthys hispanus and Ophichthys imberbis. He found that certain features are common to the eggs and larva of the ophichthyid eels studied by him and stated that in the eggs of $O$. serpens and $O$. hispanus the yolk mass has a peculiar stalked shape and that most of the gut patches are developed even before hatching. He also pointed out that the pigmentation of the tiny larvæ is very characteristic in all the three ophichthyid larvæ in having a number of large conspicuous pigment groups along the gut, one or more such groups in the post-anal region and a well-marked patch at the end of the tail. Schmidt also noted that the swellings of the gut (liver, etc.) are common to these species. Delsman (1933) based on his study of the eel 
CBgs and larvæ of the Java Sea pointed out that such characteristically pigmented larvæ are hatched out from eggs with an oil globule.

The eggs and larva described in this paper show the general characters mentioned by Schmidt and Delsman for the Mediterranean and Java Sea ophichthyid species. The eggs show the typical stalked nature of the yolk mass and also most of the gut and caudal patches quite distinctly, especially in the later stages of embryonic development. Similarly the later larval stages described here show the pest-anal patches also in addition to the gut and caudal patches. The gut swellings are not seen distinctly in the early larval stages and perhaps they are better developed in the later stages onfy. Specific identification of the eggs and larvæ is not possible in the absence of older larval stages and also information relating to the vertebral number of the common eels of the coastal waters, which are very essential for correlation.

Nair and Bhimachar (1950) described three types of eggs of which one showed the presence of an oil globule and in this respect resembles the egg described here. But the egg described by them is smaller in size and measures only $2.5 \mathrm{~mm}$. in diameter and the figure of the egg shows the characteristic stalked nature of the yolk. It is, therefore, likely that it belongs to the ophichthyid group even though no indication of the pigmentation is seen in the developing embryo. Larva $I I$ described by them is an ophichthyid larva since it shows the characteristic pigmentation mentioned already. But it is difficult to decide whether the egg and larva belong to the same species since the embryo is not sufficiently developed to show the distinctive pigmentation. . Egg II described by these authors apparently belong to another family since the yolk sac extends up to the anus and the anal fin terminates behind the vent unlike the condition found in the ophichthyid embryo and larva where it extends anteriorly far beyond the anus. Larva I described by them also shows a similar condition of the finfold. The straight disposition of the myotomes of the embryo and the larva, in contrast to the slightly angular nature of the myotomes of other larvæ, and their compact arrangement are generally seen in murænid larvæ only. It may be stated that these characters are also seen clearly in the photograph of the preleptocephaline stage of Murcena helena given by Schmidt and apart from the similarity in these characters, the close resemblance between Larva 1 and the larva of $M$. helena in general appearance also justifies the assumption that the egg and larva described by Nair and Bhimachar belong to Murænidæ. As in the case of the ophichthyid egg and larva, it is not possible to say whether the murænid egg and larva belong to the same species since the 


$$
11
$$


embryo is not fully formed and does not show the full complement of myotomes which is generally seen in the final stage of embryonic development only.

\section{REFERENCES}

Aiyar, R. G., Unny, M. M. and Varkey, P. M.

Bapat, S. V.

Delsman, H. C.

Jones, S. and Pantulu, V. R. . . "On some ophichthyid larva from the Indian coastal waters," Ind. Journ. Fish., 1955, 2 (1), 57-66.

Nair, R. V. and Bhimachar, B. S. "On some eel eggs and larve from the Gulf of Mannar," Schmidt, J.

"Studies on leptocephali of Madras Coast," Proc. 31st Ind. Sci. Congr. (Abstract), 1944, 85.

.. "A preliminary study of the pelagic fish eggs and larve of the Gulf of Mannar and the Palk Bay," Ind. Journ. Fish., 1955, 2 (1), 231-55.

.. "Fish eggs and larvæ from the Java Sea. 21, Eel Eggs," (2), Treubia, 1933, 14, 237-47. Proc. Ind. Acad. Sci., 1950, 31 (6), 331-38.

.. "On the identification of murænoid larvæ in their early (preleptocephaline) stages," Meddel. fra Komm. for Havund., Ser, Fiskeri, 1913, 4, (2), 1-14.

\section{Explanation of Plate}

Photograph 1. One-day old larva.

Photooraph 2. Three-day old larva. 